\title{
Persepsi Penyuluh Pertanian Lapang tentang Perannya dalam Penyuluhan Pertanian Padi di Provinsi Banten
}

\author{
The Perception of Agriculture Extension Agent \\ about Their Role in Agriculture Activity in Banten
}

\author{
Narso $^{1}$, Amiruddin Saleh ${ }^{2}$, Pang S Asngari ${ }^{2}$, dan Pudji Muljono ${ }^{2}$ \\ ${ }^{1}$ Universitas Ibnu Chaldun Jakarta \\ ${ }^{2}$ Institut Pertanian Bogor
}

\begin{abstract}
This research aim are: (1) To study perception of agriculture extension agent about their role in agriculture activity in Banten, (2) To explain of factors which have correlation with the perception of agriculture extension agents about their roles in agriculture extension activity in Banten, (3) To analysing degree of factors which have correlation with the perception of agriculture extension agents about their roles in agriculture extension activity in Banten. Research was designed with the method survey the deskriptive-korelasional. Analyse the data used the descriptive statistic and statistical analysis inferensial. For the statistic of descriptive use the frequency, percentage, mean score, total mean score and tabulation traverse, analysis of statistic inferensial used to see the relation the dependen variable with the independen variable by rank Spearman. Factors which correlate with the perception are (1) characteristic of extension agent consisted by the age, formal education, and experience; (2) physical Environment consisted by the institute, mean the work, construction and supervise, and career development; (3) social economics environment: Environment of work, partner opportunity, and access to economic resources; and (4) Motivation: achievement motivation, affiliate motivation, and power motivation.
\end{abstract}

Key word: Perception, Role, agriculture extension agent

\section{Ringkasan}

Penelitian ini bertujuan untuk (1) Mengkaji persepsi Penyuluh Pertanian Lapang (PPL) tentang perannya dalam menjalankan aktivitas penyuluhan di Provinsi Banten, (2) Mendeskripsikan faktor-faktor yang berkorelasi dengan persepsi PPL tentang perannya dalam menjalankan aktivitas penyuluhan di Provinsi Banten, (3) Menganalisis derajat faktor-faktor yang berkorelasi dengan persepsi PPL tentang perannya dalam aktivitas penyuluhan di Provinsi Banten. Hasil penelitian menunjukkan bahwa secara keseluruhan persepsi penyuluh pertanian lapang tentang perannya berada pada skor 2,7 yang berarti baik (rentang skor 1 hingga 4). Persepsi PPL tentang perannya yang memiliki skor tertinggi berturut-turut adalah peran dalam memilih dan menerapkan metode penyuluhan, peran sebagai pendamping, dan peran sebagai fasilitator dengan skor masing-masing 2,90, 2,83, dan 2,81. Faktor-faktor yang berhubungan dengan persepsi PPL adalah (1) karaktersitik penyuluh; (2) Lingkungan fisik; (3) Lingkngan sosial ekonomi:; dan (4) Motivasi: motivasi berprestasi, motivasi berafiliasi, dan motivasi kekuasaan. Beberapa variabel yang berkorelasi sangat nyata pada taraf kepercayaan 99\%, yaitu karakeristik, meliputi umur, pendidikan formal, dan masa kerja; lingkungan fisik yaitu kelembagaan, makna pekerjaan, pembinaan dan supervisi, dan pengembangan karir; lingkungan sosial ekonomi, yakni lingkungan kerja, peluang kemitraan, dan akses terhadap sumberdaya ekonomi; motivasi, meliputi motivasi berprestasi, motivasi berafiliasi, dan motivasi kekuasaan.

Kata kunci: persepsi, peran, penyuluh pertanian lapang (PPL)

\section{Pendahuluan}

Undang-Undang No 16 tahun 2006 tentang Sistem Penyuluhan Pertanian, Perikanan dan Kehutanan menyebutkan bahwa

\footnotetext{
${ }^{1}$ Korespondensi Penulis. Tlp: 08161378413

E-mail: narsoppn07@yahoo.co.id
}

penyuluhan merupakan bagian dari upaya mencerdaskan kehidupan bangsa dan memajukan kesejahteraan umum dan pemerintah berkewajiban untuk menyelenggarakannya (Tunggal, 2007). Petugas penyuluhan merupakan salah satu unsur yang memegang peranan penting dalam upaya mewujudkan cita-cita 
Jurnal Penyuluhan, Maret 2012 Vol. 8 No. 1

dalam Undang-Undang tersebut. Penyuluhan sebagai proses pendidikan nonformal, bertujuan mengarahkan perubahan ke arah perubahan yang terencana. Untuk mencapai hal tersebut diperlukan sumberdaya yang memadai termasuk tenaga penyuluhan, tidak saja dalam jumlah yang mencukupi tetapi juga memiliki kemampuan yang handal. Salah satu aspek pembangunan pertanian yang memiliki andil sangat besar adalah masalah pangan dalam hal ini padi. Penyuluhan memegang peranan penting dalam upaya mengembangkan usahatani padi.

Untuk mengembangkan potensi tersebut dibutuhkan tenaga penyuluh yang kompeten dalam menjalankan perannya. Hal tersebut dapat dilakukan apabila penyuluh sendiri memiliki persepsi yang baik akan peran tersebut.

Beberapa ahli seperti dikutip oleh Asngari (1984) mendefinisikan persepsi dengan cara yang beragam. Forgus maupun Forgus dan Melamed mendefinisikan persepsi sebagai "the process of information extraxtion," Harris dan Levey dalam The New Columbia Encyclopedia mendefinisikan persepsi sebagai "mental organization and interpretation of sensory information," Menurut Litterer persepsi adalah "the understanding or view people have of things in the world around them," sedangkan Hillgard menyebutkan bahwa "perception is the process of becoming aware of objects." Combs, Avila dan Purkey mendefinisikan persepsi sebagai berikut: "perception is the interpretation by individuals of how things seem to them especially in reference to how individual view the solves is solution to the world in wich they are involved;" Allport menyebutkan bahwa:

"perception has something to do with awareness of content upon the impression these object make upon our senses. It is the way things look to us, or the way they sound, feel, taste or smell. But perception also involves, to some degree, and understanding awareness, a meaning or a recognition of these objects."
Menurut Rakhmat (2007), persepsi adalah pengalaman tentang obyek, peristiwa, atau hubungan-hubungan yang diperoleh dengan menyimpulkan informasi dan menafsirkan pesan. Persepsi sebagaimana didefinisikan dalam kamus besar bahasa Indonesia (Balai Pustaka, 2002) adalah tanggapan atau penerimaan langsung dari sesuatu; proses seseorang mengetahui beberapa hal melalui pancainderanya. van den Ban dan Hawkins (1999) mengemukakan bahwa persepsi adalah proses menerima informasi atau stimuli dari lingkungan dan mengubahnya ke dalam kesadaran psikologis. Beberapa ahli seperti dikutip oleh Mulyana (2010) mendefinisikan persepsi secara beragam: Brian Fellow memberikan definisi persepsi sebagai proses yang memungkinkan suatu organisme menerima dan menganalisis informasi; Kennet K. Sereno dan Edward M. Bodekan menyatakan bahwa persepsi adalah sarana yang memungkinkan kita memperoleh kesadaran akan sekeliling dan lingkungan kita; Philip Goodacre dan Jennifer Follers, persepsi adalah proses mental yang menjadikan kita sadar akan banyaknya stimulus yang mempengaruhi indra kita; dan DeVito (2002) menyatakan bahwa persepsi adalah proses yang menjadikan kita sadar akan banyaknya stimulus yang mempengaruhi indera kita, dan persepsi adalah upaya pemberian makna pada stimuli inderawi.

Tujaun penelitian adalah untuk (1) Mengkaji persepsi Penyuluh Pertanian Lapang (PPL) tentang perannya dalam menjalankan aktivitas penyuluhan di Provinsi Banten, (2) Mendeskripsikan faktor-faktor yang berkorelasi dengan persepsi PPL tentang perannya dalam menjalankan aktivitas penyuluhan di Provinsi Banten, (3) Menganalisis derajat faktor-faktor yang berkorelasi dengan persepsi PPL tentang perannya dalam aktivitas penyuluhan di Provinsi Banten

\section{Metode Penelitian}

Penelitian dirancang dengan metode survei deskriptif-korelasional. Menurut Kerlinger dan Lee (2000), penelitian survei mengkaji populasi (universe) yang besar dengan menyeleksi serta mengkaji sampel yang dipi- 
lih dari populasi tersebut. Salah satu keuntungan utama dari penelitian survei adalah memungkinkannya pembuatan generalisasi untuk populasi yang besar.

Analisis data menggunakan statistik deskriptif dan analisis statistik inferensial. Untuk statistik deskriptif menggunakan frekuensi, persentase, rataan skor, total rataan skor dan tabulasi silang, kemudian dilakukan analisis statistika inferensial yang digunakan untuk melihat hubungan antar variabel terikat dengan variabel bebas adalah dengan menggunakan analisis korelasi rank Spearman.

\section{Hasil dan Pembahasan}

\section{Persepsi Penyuluh tentang Perannya}

Persepsi penyuluh tentang peran mereka dalam kegiatan penyuluhan yang diamati dalam penelitian ini adalah pengertian Penyuluh Pertanian Lapang tentang berbagai peran yang dilakukannya dalam kegiatan penyuluhan, meliputi: peran sebagai pendidik, komunikator, konsultan, motivator/pendorong, pendamping, perencana, analisator, ahli evaluasi kegiatan dan hasil penyuluhan, ahli dalam memilih dan menggunakan metode penyuluhan, ahli teknik pertanian, ahli analisis bisnis/kewirausahaan, dan fasilitator. Hasil penelitian mengenai persepsi penyuluh tentang perannya disajikan dalam Tabel 1 .

Tabel 1. Persepsi penyuluh tentang perannya

\begin{tabular}{lc}
\hline \multicolumn{1}{c}{ Peran penyuluh } & Rataan Skor* \\
\hline Pendidik & 2,48 \\
Komunikator & 2,69 \\
Konsultan & 2,75 \\
Motivator/pendorong & 2,59 \\
Pendamping & 2,83 \\
Perencana & 2,67 \\
Analisator & 2,71 \\
Ahli evaluasi kegiatan dan hasil & 2,68 \\
penyuluhan & \\
Ahli dalam memilih dan & 2,90 \\
menerapkan metode penyuluhan & 2,60 \\
Ahli teknik pertanian & 2,73 \\
Ahli analisis bisnis/ kewirausahaan & 2,81 \\
Fasilitator & $\mathbf{2 , 7 0}$ \\
\hline \multicolumn{2}{c}{ Rataan skor }
\end{tabular}

Keterangan: * Interval Skor 1,00 - 1,74 = Sangat rendah; 1,75 - 2,49 = Rendah; 2,50 - 3,24 = Tinggi; $3,25-4=$ Sangat tinggi
Tabel 1 menunjukkan bahwa secara keseluruhan persepsi penyuluh pertanian lapang tentang perannya berada pada skor 2,70 (tinggi) dengan skala 1 hingga 4 . Skor perspesi yang tertinggi adalah tentang peran dalam memilih dan menerapkan metode penyuluhan dengan skor 2,90 (tinggi). Sebagai penyuluh pertanian lapang yang berhubungan langsung dengan petani, penyuluh dituntut untuk menguasai berbagai metode penyuluhan, dapat menerapkannya dengan baik, dan mampu memadukan berbagai jenis metode dalam setiap pertemuan dengan petani.

Persepsi penyuluh lainnya dengan skor tinggi adalah peran sebagai pendamping dan sebagai fasilitator, dengan skor 2,83 dan 2,81 . Berdasarkan pengamatan di lapangan, beberapa peran yang dilakukan penyuluh sebagai pendamping meliputi pendampingan terhadap petani terutama dalam menggunakan teknologi atau inovasi pertanian di mana petani baru pertama kali diperkenalkan dengan teknologi tersebut.Selain itu, beberapa hal penting yang memerlukan pendampingan adalah perencanaan usahatani seperti penanaman, pemumpukan, aplikasi pestisida, panen, dan pasca panen, hal-hal tersebut merupakan kegiatan rutin yang sudah biasa dilakukan oleh penyuluh.Peran yang dilakukan penyuluh sehubungan dengan fasilitator meliputi fasilitasi dalam pembentukan kelompok tani, pembukuan usahatani, penentuan modal dan fasilitasi dalam melakukan peminjaman modal usaha.

Peran penyuluh yang memiliki skor persepsi paling rendah di antara keduabelas peran yang diteliti adalah peran penyuluh sebagai pendidik dan peran sebagai motivator dengan masing-masing skor 2,48 dan 2,59. Peran yang dilakukan penyuluh sebagai pendidik meliputi peran dalam mengelola pembelajaran seperti merencanakan, melaksanakan dan melakukan evaluasi.Selain itu, penyuluh juga berperan dalam mengelola pelatihan seperti merumuskan tujuan pelatihan, membuat materi pelatihan dan melakukan evaluasi pelatihan. Peran-peran tersebut kurang mendapatkan perhatian serius dari penyuluh, padahal peran sebagai pendidik adalah peran 
Jurnal Penyuluhan, Maret 2012 Vol. 8 No. 1

utama seorang penyuluh, yang mana mereka dituntut tidak hanya sekedar menyampaikan informasi kepada petani, tetapi juga mendidik mereka sehingga memiliki kemampuan dan keterampilan agar dapat berusahatani dengan baik dan meningkatkan taraf hidupnya.

Peran sebagai motivator juga memperoleh skor persepsi yang rendah dibandingkan dengan skor peran-peran lainnya.Peran sebagai seorang motivator yang seharusnya dilakukan oleh penyuluh adalah memotivasi petani untuk selalu semangat dalam menjalankan usahataninya, mendorong mereka untuk aktif dalam organisasi seperti kelompok tani atau gabungan kelompok tani.Selain itu, dorongan kepada petani untuk selalu mencoba bahkan menciptakan sendiri inovasi yang berhubungan dengan bidang usahatani yang digeluti, juga mendorong mereka untuk menciptakan kewirausahaan. Penjelasan terhadap masing-masing indikator persepsi PPL terhadap perannya disajikan dalam uraian berikut.

\section{Peran Penyuluh Sebagai Pendidik}

Persepsi penyuluh sebagai pendidik sebagaimana ditampilkan dalam Tabel 1 terdiri atas tiga indikator yaitu peran dalam mengelola pembelajaran, peran dalam mengelola pelatihan, dan peran dalam menyusun materi penyuluhan, dengan skor masing-masing berturut-turut 2,56, 2,60, dan 2,38. Skor tertinggi adalah peran dalam mengelola pelatihan. Berdasarkan hasil wawancara mendalam, kegiatan pelatihan merupakan salah satu teknik penyuluhan yang banyak digunakan oleh penyuluh dalam mengajarkan petani tentang berbagai hal seperti penerapan teknologi budidaya dan aplikasi peralatan pertanian terbaru.Sehingga peran-peran tersebut lebih banyak dilakukan oleh penyuluh disbandingkan dengan penyuluhan dengan memberikan materi tertentu kepada petani.

\section{Peran Penyuluh \\ Sebagai Komunikator}

Terdapat lima indikator yang menjelaskan persepsi penyuluh terhadap perannya sebagai komunikator yaitu peran dalam mengelola komunikasi inovasi (skor 2,74), peran dalam memandu sistem jaringan (skor 2,72), peran dalam memanfaatkan media komunikasi (skor 2,63), peran dalam komunikasi tatap muka (skor 2,63), dan peran dalam membangun kemitraan. Persepsi penyuluh terhadap perannya dalam mengelola kkomunikasi inovasi memiliki skor tertinggi dibandingkan indikator lainnya.Hal ini disebabkan oleh karena kebanyakan kegiatan penyuluhan yang dilakukan penyuluh berkaitan dengan penyebaran inovasi kepada petani.Pengamatan di lokasi penelitian menunjukkan bahwa petani lebih tertarik jika penyuluh memberikan sesuatu yang sifatnya masih baru, baik tentang teknik budidaya maupun menyangkut peralatan dan sarana produksi pertanian.

\section{Peran Penyuluh sebagai Konsultan}

Hasil penelitian tentang persespsi penyuluh terhadap perannya sebagai konsultan disajikan dalam Tabel 1.

Tabel 1 menunjukkan bahwa rata-rata skor persepsi penyuluh terhadap perannya sebagai konsultan adalah 2,75 termasuk dalam kategori tinggi. Skor tersebut diperoleh dari rataan skor empat indikatornya. Dua indikator tertinggi yaitu keterbukaan petani dalam memahami masalah petani (skor 3,23) dan peran penyuluh dalam memberikan pertimbangan kepada petani terhadap pilihan penggunaan teknologi usahataninya (skor 3,15). Dua indikator lainnya adalah peran penyuluh dalam melibatkan diri dalam kegiatan usahatani petani (skor 2,23) dan keterlibatan petani dalam memecahkan masalah yang dihadapi petani (skor 2,40). Berdasarkan hal tersebut, peran penyuluh sebagai konsultan memberikan kontribusi yang baik bagi kegiatan penyuluhan terutama upaya penyuluh memahami dan memberikan solusi bagi petani, baik menyangkut teknik budidaya maupun pemasaran hasil pertanian.

\section{Peran Penyuluh Sebagai Pendamping}

Persepsi penyuluh terhadap perannya sebagai pandamping termasuk dalam kategori tinggi dengan rataan skor 2,83. Peran yang dilakukan oleh penyuluh sebagai pendamping adalah mendampingi petani dalam melakukan 
kegiatan usahataninya (skor 3,15), memberkan petunjuk teknis bagi setiap kegiatan yang dilakukan petani (skor 2,23), mendampingi petani dalam penerapan inovasi pertanian (skor 3,07), dan mendampingi petani dalam melakukan perencanaan usahataninya (skor 2,86). Pendampingan yang selalu dilakukan menurut hasil wawancara dengan penyuluh adalah pendampingan terkait perencanaan usahatani dan penerapan inovasi pertanian. Sedangkan hal-hal yang bersifat teknik budidaya kurang dilakukan karena petani telah mengetahui cara-cara yang perlu dilakukan terkait teknik budidaya pertanian.

\section{Peran Penyuluh sebagai Motivator/Pendorong}

Tabel 1 menunjukkan bahwa rataan skor persepsi penyuluh terhadap perannya sebagai motivator/pendorong termasuk kategori tinggi, yakni 2,59. Hal-hal yang dilakukan penyuluh terkait perannya sebagai pendorong atau motivator adalah memberikan motivasi atau dorongan kepada petani untuk selalu memajukan usahataninya (skor 3,11), mendorong petani untuk mengembangkan potensi yang dimiliki dengan membentuk kelompok tani (skor 2,03), mendorong petani untuk menciptakan sendiri teknologi usahatani atau berinovasi (skor 3,02), dan mendorong petani untuk berwirausaha (skor 2,19).

Indikator yang menunjukkan tertinggi dalam peran penyuluh sebagai motivator adalah peran dalam mendorong petani untuk maju dan mendorong petani untuk menciptakan inovasi pertanian. Menurut penyuluh, hal-hal yang bersifat inovasi lebih disenangi petain, sehingga dalam melakukan peran sebagai motivator, selalu berkaitan dengan inovasi dan teknik pertanian terbaru.

\section{Peran Penyuluh sebagai Perencana}

Peran penyuluh sebagai perencana termasuk dalam kategori tinggi dengan skor 2,67 . Indikator yang menunjukkan skor tertinggi di antara empat indikator peran sebagai perencana adalah membuat rencana program penyuluhan (skor 3,42) dan membantu petani membuat rencana usaha (skor 3,02). Indikator lainnya memiliki rataan skor lebih rendah yaitu membuat perencanaa kegiatan penyuluhan (skor 2,00), dan membantu petani membuat rencana pemasaran hasil pertanian $(2,25)$. Indikator peran sebagai perencana dengan skor tinggi menurut penyuluh merupakan kegiatan rutin yang telah dilakukan oleh penyuluh karena merupakan tugas yang telah ditetapkan.

\section{Peran Penyuluh sebagai Analisator}

Persepsi penyuluh terhadap perannya sebagai analisator termasuk dalam kategori tinggi dengan skor 2,71. Hal-hal yang dilakukan penyuluh terkait perannya sebagai analisator adalah melakukan analisis situasi dan masalah untuk menyusun perencanaan program penyuluhan (skor 3,11), membantu petani melakukan analisis usahatani (skor 2,22), melakukan analisis masalah yang dihadapi petani terkait usahataninya (skor 3,26), dan melakukan analisis kelembagaan petani $(2,24)$. Beberapa indikator peran penyuluh sebagai analisator yang menunjukkan skor tinggi $(3,11$ dan 3,26 ) menurut keterangan hasil wawancara dengan penyuluh, merupakan kagiatan rutin yang telah menjadi tugasnya selama ini, sedangkan dua indikator peran sebagai analisator memiliki skor lebih rendah, hal ini karena hal tersebut tidak manjadi bagian dari kegiatan penyuluhan selama ini.

\section{Peran Penyuluh sebagai Ahli Evaluasi Kegiatan dan Hasil Penyuluhan}

Persepsi penyuluh terhadap perannya sebagai ahli evaluasi kegiatan dan hasil penyuluhan termasuk kategori tinggi dengan rataan skor 2,68. Indikator persepsi penyuluh terhadap perannya sebagai ahli evaluasi kegiatan dan hasil penyuluhan yang memiliki skor paling tinggi adalah peran penyuluh dalam melakukan evaluasi hasil penyuluhan (skor 3,14 ) dan peran penyuluh dalam menguasai teknik evaluasi penyuluhan (skor 3,28). Indikator lainnya yang memiliki skor lebih rendah adalah peran penyuluh dalam melakukan pemetaan hasil evaluasi untuk kegiatan penyuluhan selanjutnya (skor 2,25) dan peran penyuluh dalam menguasai teknik pengumpulan data untuk kegiatan evaluasi penyuluhan (skor 2,03). Evaluasi kegiatan dan hasil penyuluhan 
Jurnal Penyuluhan, Maret 2012 Vol. 8 No. 1

merupakan bagian dari rancanagan programa penyuluhan yang disusun dan dikerjakan oleh penyuluh setiap tahunnya, sehingga rataan skor peran tersebut termasuk tinggi.

\section{Peran Penyuluh sebagai Ahli dalam Memilih dan Menerapkan Metode Penyuluhan}

Persepsi penyuluh terhadap perannya sebagai ahli dalam memilih dan menerapkan metode penyuluhan termasuk kategori tinggi dengan rataan skor 2,90. Dua indikator yang menunjukkan skor tertinggi adalah menguasai berbagai metode penyuluhan (skor 3,35) dan ahli dalam memilih metode penyuluhan yang tepat sesuai kondisi petani. Indikator lainnya yang memiilki skor lebih rendah adalah menerapkan metode penyuluhan dengan baik (skor 2,45) dan mengkombinasikan berbagai metode dalam kegiatan penyuluhan (skor 2,35). Berdasarkan pengamatan di lokasi penelitian, dalam hal penguasaan metode penyuluhan, penyuluh tidak mengalami masalah karena hal tersebut merupakan inti dari kegiatan penyuluh. Setiap penyuluh harus dapat memahami dan menerapkan metode penyuluhan, baik diperoleh melalui pendidikan maupun pelatihan ketika sudah menjadi penyuluh.Oleh karena itu, penguasaan metode penyuluhan menjadi prioritas utama bagi penyuluh yang kompeten.

\section{Peran Penyuluh sebagai Ahli Teknik Pertanian}

Persepsi penyuluh terhadap perannya sebagai ahli teknik pertanian termasuk kategori tinggi dengan rataan skor 2,60. Indikator peran penyuluh sebagai ahli teknik pertanian adalah menguasai teknik pertanian tanaman pangan (skor 3,16), menguasai teknologi pertanian (skor 1,92), menguasai teknik pemupukan dan aplikasi pestisida (skor 3,15), dan menguasai teknik budidaya pertanian hortikultura (skor 2,16). Kebanyakan penyuluh menilai bahwa menguasai teknologi pertanian bukan menjadi bagian dari peran penyuluh dalam melaksanakan kegiatan penyuluhan, oleh karena itu indikator tersebut memiliki nilai sangat rendah.Lain halnya dengan indika- tor peran penyuluh dalam menguasai teknik budidaya pertanian dan teknik pemupukan dan aplikasi pestisida, penyuluh menilai peran tersebut merupakan peran yang harus dimiliki sehingga memiliki nilai skor tinggi.

\section{Peran Penyuluh sebagai Ahli Analisis Bisnis/Kewirausahaan}

Persepsi penyuluh terhadap perannya sebagai ahli analisis bisnis/kewirausahaan termasuk kategori tinggi dengan rataan skor 2,73. Beberapa indikator peran penyuluh sebagai ahli analisis bisnis/kewirausahaan adalah peran sebagai ahli analisis usahatani (skor 3,25 ), peran sebagai ahli analisis pembiayaan usahatani (skor 2,31 peran sebagai ahli analisis pemasaran hasil pertanian (skor 3,05 ), dan peran sebagai ahli analisis bisnis pertanian (skor 2,31). Sebagai ahli analisis bisnis/ kewirausahaan, penyuluh dituntut untuk memahami berbagai hal yang berhubungan dengan kewirausahaan, termasuk pemasaran hasil pertanian, sehingga peran sebagai ahli analisis bisnis/kewirausahaan dapat dijalankan dengan baik.

\section{Peran Penyuluh sebagai Fasilitator}

Persepsi penyuluh terhadap perannya sebagai fasilitator termasuk dalam kategori tinggi dengan skor 2,81. Beberapa indikator peran penyuluh sebagai fasilitator adalah peran penyuluh dalam memfasilitasi petani membentuk kelompok tani (skor 3,38), peran dalam memfasilitasi petani menemukan mitra usaha (skor 2,30), memfasilitasi petani membuat rencana usahataninya (skor 3,10), dan memfasilitasi petani mengelola bisnis pertanian (skor 2,45). Kegiatan penyuluhan sangat berkaitan dengan kegiatan fasilitasi, terutama dalam memfasilitasi petani terhadap hal-hal yang berhubungan dengan usahatani yang ditekuni. Berdasarkan hasil wawancara, penyuluh telah terbiasa memfasilitasi petani, terutama dalam pengelolaan kelompok tani dan perencanaan usahatani, sehingga peran-peran tersebut dapat dilakukan dengan baik. 


\section{Faktor-Faktor yang Berhubungan dengan Persepsi Penyuluh tentang Perannya}

Pengukuran untuk menentukan faktorfaktor yang berhubungan dengan persepsi penyuluh tentang perannya dilakukan terhadap beberapa faktor seperti karakteristik penyuluh, lingkungan fisik, lingkungan sosial ekonomi, dan motivasi kerja.

\section{Karakteristik Penyuluh}

Analisis yang digunakan untuk menentukan hubungan karakteristik penyuluh terhadap persepsi penyuluh tentang perannya adalah korelasi rank Spearman. Hasil penelitian tentang hubungan karakteristik penyuluh dengan persepsi penyuluh tentang perannya disajikan dalam Tabel 21.

Tabel 21. Hubungan karakteristik dengan persepsi penyuluh tentang perannya

\begin{tabular}{lc}
\hline $\begin{array}{c}\text { Karakteristik } \\
\text { Penyuluh }\end{array}$ & $\begin{array}{c}\text { Koefisien Korelasi Rank Spearman } \\
\text { terhadap Persepsi Penyuluh tentang } \\
\text { Perannya }\end{array}$ \\
\hline Umur & $0,705^{* *}$ \\
Pendidikan & $0,747^{* *}$ \\
formal & $0,864 * *$ \\
Masa Kerja & 0,134 \\
Pelatihan & 0,106 \\
Pendapatan & Keterangan: $* *$ Berkorelasi sangat nyata pada $\alpha=0,01$
\end{tabular}

Tabel 2 menunjukkan bahwa dari lima indikator karakteristik yang dianalisis, terdapat tiga indikator yang menghasilkan korelasi sangat nyata pada taraf kepercayaan 99 persen, yaitu umur, pendidikan formal, dan masa kerja. Sedangkan dua indikator karakteristik penyuluh seperti pelatihan dan pendapatan tidak menunjukkan adanya korelasi yang nyata dengan persepsi penyuluh tentang perannya.

Umur merupakan usia penyuluh yang diukur menurut satuan tahun. Hasil analisis menunjukkan koefisien korelasi rank Spearman antara umur dengan persepsi adalah 0,705 dengan taraf kepercayaan 99 persen atau sangat nyata. Hal ini berarti semakin tinggi umur semakin baik persepsi penyuluh tentang perannya. Menurut Padmowihardjo (1994) umur bukan merupakan faktor psikologis, tetapi apa yang diakibatkan oleh umur adalah faktor psikologis. Terdapat dua faktor yang menentukan kemampuan seseorang berhubungan dengan umur.Faktor pertama ialah mekanisme belajar dan kematangan otak, organ-organ sensual, dan otot organ-organ tertentu. Faktor kedua adalah akumulasi pengalaman dan bentuk-bentuk proses belajar yang lain. Berdasarkan hal tersebut, akumulasi pengalaman penyuluh merupakan hal penting yang membentuk persespi terkait peran yang merupakan tugas pokok penyuluh pertanian lapang.

Pendidikan formal menunjukkan hubungan sangat nyata terhadap persepsi penyuluh tentang perannya, berdasarkan hasil analisis rank Spearman dengan koefisien korelasi 0,747 pada taraf kepercayaan 99 persen. Pendidikan formal penyuluh diukur berdasarkan jumlah tahun penyuluh menempuh pendidikan formal.Pendidikan formal dapat menimbulkan perubahan-perubahan pada individu, baik perubahan secara intelektual maupun emosional dan keterampilan. Menurut Soeitoe (1982), pendidikan adalah suatu proses yang diorganisir dengan tujuan mencapai sesuatu hasil yang nampak sebagai perubahan dalam tingkah laku. Pendidikan memberikan nilainilai tertentu bagi manusia, terutama dalam membuka pikiran serta menerima hal-hal baru dan juga bagaimana cara berpikir secara ilmiah. Penyuluh pertanian lapang di Provinsi Banten memiliki tingkat pendidikan yang cukup tinggi, yaitu rata-rata sarjana strata satu, bahkan beberapa strata dua. Faktor pendidikan memegang peranan penting dalam membentuk perilaku dan persepsi seorang penyuluh dalam menjalankan tugas dan fungsinya.

\section{Lingkungan Fisik}

Tabel 3 menunjukkan bahwa beberapa indikator lingkungan fisik seperti kelembagaan, makna pekerjaan, pembinaan dan supervisi, dan pengembangan karir menunjukkan hubungan sangat nyata dengan persepsi penyuluh tentang perannya. Adapun indikator lainnya seperti luas wilayah binaan dan jumlah petani binaan tidak menunjukkan hubungan nyata dengan persepsi penyuluh tentang perannya. 
Jurnal Penyuluhan, Maret 2012 Vol. 8 No. 1

Tabel 3. Hubungan lingkungan fisik dengan persepsi penyuluh tentang perannya

\begin{tabular}{lc}
\hline Lingkungan Fisik & $\begin{array}{c}\text { Koefisien Korelasi Rank } \\
\text { Spearman terhadap Persepsi } \\
\text { Penyuluh tentang Perannya }\end{array}$ \\
\hline Kelembagaan & $0,881^{* *}$ \\
Makna pekerjaan & $0,904^{* *}$ \\
Luas wilayah binaan & 0,130 \\
Jumlah petani binaan & 0,116 \\
Pembinaan dan & $0,685^{* *}$ \\
supervisi & $0,666^{* *}$ \\
Pengembangan karir
\end{tabular}

Kelembagaan penyuluh dinyatakan sebagai bentuk dukungan yang diberikan kelembagaan terkait tugas dan peran yang harus dijalankan oleh penyuluh. Hasil analisis korelasi rank Spearman menunjukkan hubungan sangat nyata dengan koefisien 0,881 pada taraf kepercayaan 99\%. Hal ini berarti semakin baik dukungan kelembagaan semakin baik pula persepsi penyuluh tentang perannya. Penyuluh pertanian dalam melaksanakan tugasnya perlu mendapatkan dukungan dari lembaga atau institusi tempatnya bernaung, Dukungan tidak hanya dari segi kebijakan, tetapi juga dari segi fasilitas dan operasional di lapangan. Menurut Winardi (2003), kelembagaan/organisasi secara efektif dapat menghasilkan manfaat/keuntungan di antaranya: Kejelasan tentang ekspektasi-ekspektasi kinerja individual dan tugas-tugas yang terspesialisasi; Pembagian kerja, yang menghindari timbulnya duplikasi, konflik, dan penyalahgunaan sumber daya-sumber daya, baik sumberdaya material maupun sumberdaya manusia.

Hasil analisis rank Spearman antara makna pekerjaan dengan persepsi penyuluh tentang perannya menunjukkan hubungan yang sangat nyata dengan koefisien korelasi sebesar 0,904 pada taraf kepercayaan 99\%. Artinya, semakin baik makna pekerjaan semakin baik pula persepsi penyuluh tentang perannya. Menurut Hackman dan Oldham (Armansyah, 2002), terdapat tiga karaktersitik pekerjaan yang dihipotesiskan mempengaruhi persepsi seseorang terhadap pekerjaannya yaitu (1) variasi keterampilan, (2) identitas tugas, dan (3) signifikansi tugas. Derajat variasi kegiatan dalam suatu pekerjaan menentukan pemaknaan seseorang terhadap pekerjaannya. Bila suatu tugas mempersyaratkan seseorang untuk menggunakan aktivitas-aktivitas yang menantang atau menggunakan seluruh keahlian dan keterampilannya, maka mereka cenderung memiliki persepsi pekerjaan tersebut penuh makna. Penyuluh pertanian lapang di Provinsi Banten dapat menjalankan tugas dan perannya dengan baik, hal ini tidak terlepas dari adanya kejelasan uraian tugas yang diberikan, selain itu, para penyuluh memiliki pengetahuan dan keterampilan yang baik dalam melaksanakan tugas dan peran-peran tersebut.

Pembinaan dan supervisi menunjukkan hubungan sangat nyata dengan persepsi penyuluh tentang perannya. Hal ini terlihat dari hasil analisis rank Spearman yang manghasilkan koefisien korelasi sebesar 0,685 pada taraf kepercayaan 99 persen. Berarti semakin baik pembinaan dan supervisi semakin baik pula persepsi penyuluh tentang tugas dan perannya. Pengawasan atau supervisi mencakup teknik pengawasan (supervisi) yaitu efektivitas pengawas, keahlian manajemennya, pengetahuan, kesuksesan dan kemampuan dalam memecahkan masalah; dan hubungan dengan pengawas (relationship with supervisor). Menurut Vijayaragavan dan Sing (1998), dua fungsi utama supervisi adalah orientasi tugas dan pertimbangan bagi petugas atau pegawai, karena itu arah dan aktivitas organisasi, motivasi pegawai dan manajemen dari kelompok kerja merupakan hal penting bagi supervisor.

Hasil analisis rank Spearman antara pengembangan karir dengan persepsi penyuluh tentang perannya menunjukkan hubungan yang sangat nyata dengan nilai koefisien korelasi sebesar 0,666 pada taraf kepercayaan 99 persepsi. Hal ini berarti bahwa semakin baik pengembangan karir semakin baik pula persepsi penyuluh tentang perannya.Penyuluh pertanian lapang di Provinsi Banten sesuai dengan ketentuan dari Kementerian Pertanian dapat mengembangkan karir ke tingkat jabatan fungsional yang lebih tinggi jika dapat mencukupi persyaratan jumlah angka kredit kumulatif minimal. Promosi merupakan bentuk pengembangan karir yaitu peningkatan jabatan seseorang ke tingkat yang lebih tinggi 
gajinya, tanggung jawab, dan level organisasinya, biasanya diberikan sebagai penghargaan terhadap kinerjanya. Menurut Swinyard dan Bond (Werther \& Davis, 1989), umumnya promosi diberikan sebagai penghargaan terhadap nilai kesuksesan kinerja (merit-based promotions) dan terhadap senioritas (seniority-based promotion).

\section{Lingkungan Sosial Ekonomi}

Tabel 4 menunjukkan bahwa terdapat tiga indikator lingkungan sosial ekonomi yang berhubungan sangat nyata dengan persepsi penyuluh tentang perannya, yakni lingkungan kerja, peluang kemitraan, dan akses terhadap sumberdaya ekonomi.

Tabel 4. Hubungan lingkungan sosial ekonomi dengan persepsi penyuluh tentang perannya

\begin{tabular}{|c|c|}
\hline $\begin{array}{l}\text { Lingkungan Sosial } \\
\text { Ekonomi }\end{array}$ & $\begin{array}{c}\text { Koefisien Korelasi Rank } \\
\text { Spearman terhadap } \\
\text { Persepsi Penyuluh tentang } \\
\text { Perannya }\end{array}$ \\
\hline Lingkungan kerja & $0,611 * *$ \\
\hline Peluang kemitraan & $0,875 * *$ \\
\hline $\begin{array}{l}\text { Akses terhadap } \\
\text { sumberdaya ekonomi }\end{array}$ & $0,878 * *$ \\
\hline Akses terhadap media & 0,051 \\
\hline
\end{tabular}

Hasil analisis rank Spearman terhadap lingkungan kerja dengan persepsi penyuluh tentang perannya menunjukkan hubungan yang sangat nyata dengan nilai koefisien korelasi 0,611 pada taraf kepercayaan 99 persen. Menurut Herzberg (Daniel, 2004), lingkungan kerja mencakup kondisi fisik lingkungan kerja, jumlah pekerjaan, suasana kerja dan fasilitas tempat kerja. Termasuk juga pencahayaan di ruang kerja, ventilasi, sarana, ruangan dan berbagai faktor lingkungan lainnya.Selain hal tersebut dalam penyuluhan kondisi kerja yang dimaksud juga mencakup luas wilayah kerja penyuluh dan jumlah kepala keluarga petani.

Hubungan sangat nyata juga ditunjukkan dari hasil analisis korelasi antara peluang kemitraan dengan persepsi penyuluh tentang perannya dengan koefisien korelasi sebesar 0,875 pada taraf kepercayaan 99 persen.Hal ini berarti semakin baik peluang kemitraan semakin baik persepsi penyuluh tentang perannya. Adanya kemitraan dari pihak luar dapat membantu penyuluh dalam usaha membantu petani meningkatkan produksi usahanya sekaligus meningkatkan pendapatan dan taraf hidupnya.

Akses terhadap sumberdaya ekonomi menunjukkan hubungan yang sangat nyata dengan persepsi penyuluh tentang perannya. Nilai koefisien korelasi yang dihasilkan adalah 0,878 pada taraf kepercayaan 99 persen. Semakin baik akses terhadap sumberdaya ekonomi maka semakin baik pula persepsi penyuluh tentang perannya. Akses ekonomi merupakan kesempatan yang mendukung penyuluh untuk membantu petani memecahkan masalah-masalah ekonomi usahataninya, baik secara individu maupun kelompok dari pihak luar. Menurut Hernanto (1993), faktorfaktor ekonomi yang dapat berpengaruh terhadap produksi usahatani antara lain adalah: cabang usaha, faktor produksi khususnya modal dan sumber modal yang diperoleh. Dalam upaya mengatasi faktor atau masalah usahatani, terdapat keputusan yang harus berdasarkan prinsip-prinsip ekonomi yaitu: (1) menentukan kegiatan apa saja yang sebaiknya dilaksanakan di dalam perusahaan, (2) menentukan jumlah berbagai faktor produksi yang harus dipakai setiap tahun, (3) menentukan jumlah modal yang diperlukan, (4) memilih sumber modal yang baik, (5) menentukan jumlah modal yang sebaiknya diambil dari setiap sumber yang dipilih.

\section{Motivasi}

Tabel 5 menunjukkan bahwa semua indikator motivasi menunjukkan hubungan yang sangat nyata dengan persepsi penyuluh tentang perannya, yaitu meliputi motivasi berprestasi, motivasi berafiliasi, dan motivasi kekuasaan.

Tabel 5. Hubungan motivasi dengan persepsi penyuluh tentang perannya

\begin{tabular}{lc}
\hline Motivasi & $\begin{array}{c}\text { Koefisien Korelasi Rank Spearman } \\
\text { terhadap Persepsi Penyuluh tentang } \\
\text { Perannya }\end{array}$ \\
\hline Motivasi berprestasi & $0,668^{* *}$ \\
Motivasi berafiliasi & $0,899^{* *}$ \\
Motivasi kekuasaan & $0,616^{* *}$ \\
\hline Keterangan: **
\end{tabular}

Keterangan: $* *=$ Berkorelasi sangat nyata pada $\alpha=0,01$ 
Jurnal Penyuluhan, Maret 2012 Vol. 8 No. 1

Hasil analisis korelasi antara motivasi berprestasi dengan persepsi penyuluh tentang perannya menunjukkan hubungan yang sangat nyata dengan nilai koefisien korelasi sebesar 0,668 pada taraf kepercayaan 99 persen. Hal ini berarti bahwa tingginya motivasi berprestasi akan meningkatkan nilai persepsi penyuluh tentang perannya. Kebutuhan akan prestasi merupakan daya penggerak yang memotivasi semangat bekerja seseorang. Karena itu, hal tersebut akan mendorong seseorang untuk mengembangkan kreativitas dan mengarahkan semua kemampuan serta energi yang dimilikinya demi mencapai prestasi kerja yang maksimal. Menurut Robbins (1994), karyawan akan antusias untuk berprestasi tinggi, asalkan kemungkinan untuk itu diberi kesempatan. Seseorang menyadari bahwa hanya dengan mencapai prestasi kerja yang tinggi akan dapat memperoleh pendapatan yang besar. Dengan pendapatan yang besar akhirnya memiliki serta memenuhi kebutuhan-kebutuhannya.

Motivasi berafiliasi menunjukkan hubungan yang sangat nyata dengan persepsi penyuluh tentang perannya. Hal ini terlihat dari hasil analisis rank Spearman dengan nilai koefisien korelasi sebesar 0,899 pada taraf kepercayaan 99 persen. Artinya, adanya motivasi berafiliasi dapat meningkatkan nilai persepsi penyuluh tentang perannya. Kebutuhan akan afiliasi menjadi daya penggerak yang akan memotivasi semangat bekerja seseorang. Oleh karena itu, kebutuhan ini merangsang gairah bekerja karyawan karena setiap orang menginginkan hal-hal: kebutuhan akan perasaan diterima oleh orang lain di lingkungan ia tinggal dan bekerja (sense of belonging), kebutuhan akan perasaan dihormati, karena setiap manusia merasa dirinya penting (sense of importance), kebutuhan akan perasaan maju dan tidak gagal (sense of achievement), dan kebutuhan akan perasaan ikut serta (sense of patcipation) (Robbins, 1994).

Hasil analisis korelasi rank Spearman antara motivasi kekuasaan dengan persepsi penyuluh tentang perannya menunjukkan hubungan sangat nyata dengan nilai koefisien korelasi sebesar 0,616 pada taraf kepercayaan 99 persen. Motivasi kekuasaan dapat meningkatkan nilai persepsi penyuluh tentang peran- nya. Kebutuhan akan kekuasaan merupakan daya penggerak yang memotivasi semangat kerja karyawan. Kebutuhan tersebut akan merangsang dan memotivasi gairah kerja karyawan serta mengarahkan semua kemampuannya demi mencapai kekuasaan atau kedudukan yang terbaik. Ego manusia ingin lebih berkuasa dari manusia lainnya akan menimbulkan persaingan. Persaingan ditumbuhkan secara sehat oleh manajer dalam memotivasi bawahannya, supaya mereka termotivasi untuk bekerja giat (Robbins, 1994).

\section{Kesimpulan}

Persepsi PPL tentang perannya yang memiliki skor tertinggi berturut-turut adalah peran dalam memilih dan menerapkan metode penyuluhan, peran sebagai pendamping, dan peran sebagai fasilitator dengan skor masingmasing 2,90, 2,83, dan 2,81. Tiga peran yang dipersepsikan dengan skor rendah berturutturut adalah peran penyuluh sebagai pendidik, peran sebagai motivator, dan peran sebagai ahli teknik pertanian dengan skor masingmasing 2,48, 2,59, dan 2,60.

Faktor-faktor yang berhubungan dengan persepsi PPL adalah (1) karaktersitik penyuluh terdiri atas umur, pendidikan formal, dan masa kerja; (2) Lingkungan fisik terdiri atas kelembagaan, makna pekerjaan, pembinaan dan supervisi, dan pengembangan karir; (3) Lingkngan sosial ekonomi: Lingkungan kerja, peluang kemitraan, dan akses terhadap sumberdaya ekonomi; dan (4) Motivasi: motivasi berprestasi, motivasi berafiliasi, dan motivasi kekuasaan. Beberapa variabel yang berkorelasi sangat nyata pada taraf kepercayaan 99\%, yaitu karakeristik, meliputi umur, pendidikan formal, dan masa kerja; lingkungan fisik yaitu kelembagaan, makna pekerjaan, pembinaan dan supervisi, dan pengembangan karir; lingkungan sosial ekonomi, yakni lingkungan kerja, peluang kemitraan, dan akses terhadap sumberdaya ekonomi; motivasi, meliputi motivasi berprestasi, motivasi berafiliasi, dan motivasi kekuasaan. 
Jurnal Penyuluhan, Maret 2012 Vol. 8 No. 1

\section{Daftar Pustaka}

Armansyah. 2002. "Growth Need Strength sebagai Moderator Hubungan antara Karakteristik Pekerjaan dan Kepuasan Kerja secara Umum." Tesis. Depok: Universitas Indonesia.

Asngari, P.S. 1984."Persepsi Direktur Penyuluhan Tingkat Karasidenan dan Kepala Penyuluh Pertanian terhadap Peran dan Fungsi Lembaga Penyuluhan Pertanian di Negara Bagian Texas Amerika Serikat.Jurnal Media Peternakan, Vol. 9, No, 2, 1984. Bogor: Fakultas Peternakan IPB.

Balai Pustaka. 2002. Kamus Besar Bahasa Indonesia. Jakarta: Balai Pustaka.

Daniel, D. 2004. "Does Pay Always Motivate? Debungking Four Myths about Money." http://www.Piworldwide.com. [Diakses 2 Januari 2011].

DeVito, J.A. 2002. Komunikasi Antar Manusia. Jakarta: Indonesia Professional Books.

Hernanto, F. 1993. Ilmu usahatani. Jakarta: Penebar Swadaya.

Kerlinger, F. N., Lee, H.B. 2000.Foundations of Behavioral Research. $4^{\text {th }}$ Edition. Syracase, Orlando USA: Harcourt College Publishers.
Mulyana, D. 2010. Ilmu Komunikasi: Suatu Pengantar. Bandung: Remaja Rosdakarya.

Rakhmat, J. 2007. Psikologi Komunikasi. Bandung: Remaja Rosdakarya.

Robbins, S. P. 1994. Organizational Behavior: Concept-Controversies Application New Jersey: Prentice Hall,Inc.

Soeitoe, S. 1982. Psikologi Pendidikan. Jakarta: Universitas Indonesia Press.

Tunggal, H.S. 2007.Undang-Undang Sistem Penyuluhan Pertanian, Perikanan, dan Kehutanan. Jakarta: Harvarindo.

van den Ban, A. W., Hawkins, H.S. 1999. Penyuluhan Pertanian. Penerjemah; Herdiasti, A.D. Yogyakarta: Kanisius.

Vijayaragavan, K., Singh, Y. P. 1998. "Managing Human Resources within Extension." Dalam, Improving agricultural extension.Diedit, Burton E. Swanson, Robert P. Bentz, dan Andrew J. Sofranko. Rome: Food and Agriculture Organization of the United Nations.

Winardi, J. 2003. Teori Organisasi dan Pengorganisasian. Jakarta: Raja Grafindo Persada.

Werther, W. B., Davis, J. R. 1989. Human Resources and Personnel Management. 3th Ed. USA: McGraw-Hill, Inc. 